\title{
PENGEMBANGAN BUKU IPA SD BERBASIS INKUIRI UNTUK MENINGKATKAN SIKAP ILMIAH DAN BERPIKIR KRITIS TERHADAP LINGKUNGAN DAN FENOMENA ALAM BAGI SISWA SD
}

\author{
Dalifa \\ Pendidikan Guru Sekolah Dasar \\ Fakultas Keguruan dan Ilmu Pendidikan, Universitas Bengkulu
}

\begin{abstract}
Abstrak
Penelitian Pembelajaran IPA di SD menekankan pada pemberian pengalaman langsung, inkuiri ilmiah (scientific inquiry), menumbuhkan kemampuan berpikir kritis, dan sikap ilmiah dalam bentuk kecakapan hidup (life-skills). Tujuan penelitian ini adalah untuk menghasilkan buku ajar pendidikan IPA SD berbasis inkuiri yang dapat meningkatkan kemampuan sikap ilmiah, dan berpikir kritis bagi siswa SD. Subjek penelitian ini adalah siswa SD kelas 4, 5, 6. Teknik pengumpulan data menggunakan uji coba. Data yang telah diperoleh dianalisis melalui analisis kovariat (MACNOVA) faktorial 2X2 (Hair. Et al, 1995; Sharma,1996:342-345). Hasil penelitian adalah draft buku IPA SD berbasis inkuiri yang berisi : (1) uraian kompetensi siswa, (2) judul bab, (3) gambar pembuka bab, (4) teks pengantar, (5) peta pikiran, (6) materi pelajaran, (7) gambar dan ilustrasi, (8) tahukah kamu, (9) mari mencari tahu, (10) mari kita selidiki, (11) mari bertukar pikiran, dan (12) mari mengingat kembali. Berdasarkan hasil penelitian dapat disimpulkan yaitu isi draft buku IPA SD berbasis inkuiri yang dikembangkan, mencakup: 1) Judul bab, gambar pembuka bab, dan teks pengantar disajikan dengan tujuan untuk menarik perhatian dan memancing keingintahuan siswa ( fase Engage), 2) Tahukah kamu, berisi informasi actual agar siswa mampu memecahkan kesulitan yang dihadapi( fase Elaborate), 3) Mari cari tahu dan Mari kita selidiki, berbentuk lembar kegiatan dan diskusi disajikan untuk memberi kesempatan kepada siswa agar bekerja sama dalam menjawab pertanyaan dan melakukan pengamatan ( fase Explore).
\end{abstract}

Kata Kunci: Bahan Ajar,Inkuiri, sikap Ilmiah, Keterampilan berpikir kritis, IPA

\section{PENDAHULUAN}

Pendidikan IPA di SD diharapkan dapat menjadi wahana bagi peserta didik untuk mempelajari diri sendiri dan alam sekitar, serta menerapkannya di dalam kehidupan sehari-hari. Pembelajara IPA menekankan pada pemberian pengalaman langsung dan inkuiri ilmiah (scientific inquiry), berbuat untuk menumbuhkan kemampuan berpikir kritis, dan bersikap ilmiah serta mengkomunikasikannya sebagai aspek penting kecakapan hidup (life-skills).

IPA pada hakikatnya terdiri dari empat komponen yaitu sikap ilmiah, proses ilmiah, produk ilmiah, dan aplikasi. Penemuan atau discovery-inkuiri adalah suatu proses mental di mana anak atau individu mengasimilasi konsep dan prinsip-prinsip. Dengan strategi inkuiri, guru mengajak siswa untuk terlibat aktif baik secara fisik dan mental dalam belajarnya. Siswa diajak aktif berpikir mengenali masalah, menyelidiki untuk mencari jawaban masalah yang di hadapi sampai pada penyusunan simpulan. Siklus belajar discovery- inkuiri mencakup tiga elemen yang harus dilalui, yaitu exploration, invention, atau concept development, dan discovery aplication (Winarni, 2007b dan 2007c). 
Berdasarkan uraian di atas, muncul permasalahan, yaitu buku ajar IPA yang bagaimanakah untuk meningkatkan sikap ilmiah dan berpikir kritis bagi siswa SD? Untuk menjawab permasalahan tersebut perlu dilakukan pengembangan buku IPA SD berbasis inkuiri.

\section{METODE}

Metode yang digunakan dalam penelitian pengembangan ini adalah metode kualitatif. Penelitian pengembangan ini dimulai dengan penelitian pustaka dan penelitian empirik. Artinya, data yang menunjang penelitian ini dikumpulkan melalui penelaahan kepustakaan dan penelahaan pengamalan empirik. Penelitian pengembangan tidak hanya mengembangkan hasil, tapi menemukan pengetahuan baru (new knowledge) untuk menjawab pertanyaan khusus tentang masalah praktis.Prosedur pengumpulan data yang digunakan dalam penelitian ini adalah uji coba.

Analisis data pretest dan postest menggunakan analisis kovariat (MACNOVA) faktorial 2X2 (Hair. Et al, 1995; Sharma, 1996:342-345). Beberapa asumsi mancova, yaitu: (1) uji normalitas sebaran data variabel dependen akan dianalasis dengan statistik KolmogorovSmirnov Goodness of Fit Test dan Shapiro Wilk; (2) uji homogenitas (homogenity of variance) kelompok data menggunakan uji Levene (Levene Test).

\section{HASIL}

Hasil akhir penelitian ini adalah draft buku IPA SD berbasis inkuiri yang berisi : (1) uraian kompetensi siswa, (2) judul bab, (3) gambar pembuka bab, (4) teks pengantar, (5) peta pikiran, (6) materi pelajaran, (7) gambar dan ilustrasi, (8) tahukah kamu, (9) mari mencari tahu, (10) mari kita selidiki, (11) mari bertukar pikiran, dan (12) mari mengingat kembali.

Kompetensi siswa disajikan untuk petunjuk awal bagi guru dan siswa yang terdiri dari dua komponen, yaitu komponen identitas dan isi kompetensi. Komponen identitas berisi informasi: (1) kelas/semester, (2) judul materi, (3) standar kompetensi, dan (4) kompetesi dasar. Isi kompetensi mencakup: (1) indikator kognitif produk dan proses, afektif membangun karakter serta psikomotor; (2) kegiatan pembelajaran; dan (3) sumber belajar.

Sesuai tujuan penelitian pengembangan ini, maka berikut akan disajikan deskripsi hasil pengembangan buku ajar IPA SD kelas 4,5, dan 6. Buku ajar IPA berbasis inkuiri untuk kelas 4 SD yang dikembangkan mencakup materi: (1) Kerangka Tubuh Manusia dan Fungsinya, (2) Panca Indera Manusia dan Fungsinya, (3) Struktur dan fungsi bagian tumbuhan, (4) Penggolongan hewan berdasarkan jenis makanannya, (5) Daur Hidup Hewan, (6) Hubungan antar Makhluk Hidup (Simbiosis), (7) Gaya, (8) Energi alternatif, (9) Energi alternatif dan penggunaannya, dan (10) Keuntungan Menggunakan Sumber Daya Alam.

Buku ajar IPA berbasis inkuiri untuk kelas 5 SD yang dikembangkan mencakup materi: (1) Alat pernafasan, (2) alat pernafasan pada hewan, (3) sistem pencernaan, (4) Alat peredaran darah manusia, (5) Fotosintesis, (6) Cadangan makanan tumbuhan hijau, (7) Penyesuaian diri hewan dengan lingkungan, (8) sifat-sifat bahan, (9) perubahan sifat bahan, (10) gaya, (11) pesawat sederhana, (12) cahaya dan sifat-sifatnya, (13) Alat Optik, (14) Tanah, (15) Air dan alam sekitar.

Buku ajar IPA berbasis inkuiri untuk kelas 6 SD yang dikembangkan mencakup materi: (1) Ciri-ciri makhluk hidup, (2) Perkembangan makhluk hidup, (3) keseimbangan lingkungan, (4) pelestarian makhluk hidup, (5) Benda dan perubahannya, dan (6) Bumi dan alam semesta.

\section{PEMBAHASAN}

Penelitian Winarni (2006a; 2006b) mengemabangkan strategi pembelajaran inkuiri terbimbing dalam pembelajaran IPA dengan landasan filsafat konstruktivisme untuk menciptakan: pembelajaran aktif, terjadi interaksi 
antara gagasan dan proses belajar, konsep bermakna, pemecahan masalah lebih kompleks, dan tercipta diskusi antar siswa atau belajar secara kooperatif. Implementasi inkuiri terbimbing terwujud dalam serangkaian kegiatan: (1) kegiatan awal sebagai tahp eksplorasi ( guru menginformasikan tujuan pembelajaran, memotivasi siswa dengan menyajikan fenomna yang berkaitan dengan materi pelajaran, melakukan curah pendapat untuk memperoleh rumusan masalah, dan membagikan LKS sebagai pedoman bagi siswa penemuan jawaban permasalahan); (2) kegiatan inti sebagai tahap eksplanasi (guru memfasilitasi penyelidikan, membimbing siswa mengumpulkan data dan diskusi kelompok, mengajukan pertanyaan untuk pendalaman materi); dan (3) kegiatan penutup sebagi tahap konsolidasi dan aplikasi, pada tahap ini guru: membimbing siswa untuk pembuatan simpulan, membantu siswa melakukan evaluasi dan refleksi, mengajukan pertanyaan untuk menghubungkan konsep dan memberi tugas lanjutan untuk mengembangkan konsep yang sudah dipelajari (Winarni, 2006a).

Winarni (2009e) mengembangkan penelitian berbasis inkuiri untuk peningkatan lifeskills siswa SD yang merupakan penelitian pengembangan (Research and Development). Hasilnya melalui basis inkuiri ini, guru mengajak siswa untuk terlibat aktif baik secara fisik dan mental dalam belajarnya. Siswa diajak aktif berpikir mengenali masalah, menyelidiki untuk mencari jawaban masalah yang dihadapi sampai pada penyusunan simpulan. Hasil validasi skenario pembelajaran dan LKS oleh ahli dan guru termasuk dalam kriteria baik. Hasil pengamatan terhadap keterlaksanaan skenario pembelajaran menujukkan $80 \%$ langkah kegiatan dapat dilaksanakan dengan sangat baik. Tanggapan siswa terhadap pelaksanaan model yang dikembangkan adalah siswa merasakan: 1) ada tantangan untuk melakukan kegiatan; 2) tidak mudah menyerah dalam menjawab pertanyaan; dan 3) belajar yang menyenangkan. Hasil uji coba menunjukkan ketuntasan belajar siswa secara klasikal mengalami peningkatan sebesar $28 \%$ dan life-skills siswa mengalami peningkatan sebesar 17,66\% (Winarni, 2009e).

Isi draft buku IPA SD berbasis inkuiri yang dikembangkan, yaitu: Judul bab dicantumkan untuk mengetahui materi yang akan dipelajari. Gambar pembuka bab, merupakan gambar pembuka yang mewakili ari materi yang akan dipelajari. Teks pengantar, merupakan teks atau bacaan yang akan mengantar siswa untuk memasuki materi yang akan dipelajari. Judul bab, gambar pembuka bab, dan teks pengantar disajikan dengan tujuan untuk menarik perhatian dan memancing keingintahuan siswa (fase Engage). Peta pikiran, untuk memudahkan siswa memahami alur dari materi yang akan dipelajari (fase Engage). Materi pelajaran disajikan sebagai salah satu sumber informasi untuk pendorong agar siswa dapat membentuk konsep (fase Explain). Gambar dan ilustrasi disajikan untuk menambah motivasi siswa dalam penemuan (fase Explain). Tahukah kamu berisi informasi actual yang berkaitan dengan konsep yang dipelajari sehingga siswa mampu memecahkan kesulitan yang dihadapi baik secara individu maupun secara berkelompok ( fase Elaborate). Mari cari tahu dan mari kita selidiki berbentuk lembar kegiatan dan diskusi disajikan untuk memberi kesempatan kepada siswa agar bekerja sama dalam menjawab pertanyaan dan melakukan pengamatan (fase Explore). Mari bertukar pikiran sebagai bagian untuk pendorong agar siswa dapat menjelaskan konsep dengan kata-kata sendir atau pembentukkan konsep (fase Explain), dan mari mengingat kembali sebagai bagian untuk mengukur tingkat pemahaman siswa tentang konsep yang sduah ditemukan (fase Evaluate).

Melalui bahan ajar guru akan lebih mudah dalam melaksanakan pembelajaran dan siswa akan lebih terbantu dan mudah dalam belajar. Bahan ajar dapat dibuat dalam berbagai bentuk sesuai dengan kebutuhan dan karakteristik materi ajar yang akan disajikan. Buku ini disusun dengan harapan bermanfaat bagi semua pihak yang berkepentingan dalam pengembangan bahan ajar, seperti kepalah sekolah, guru, 
pengawas sekolah menengah atas maupun pembina pendidikan lainya.

Dengan bahan ajar memungkinkan siswa dapat mempelajari suati kompetensi atau KD secara runtut dan sistematis sehingga secara akumulatif mampu menguasai semua kompetensi secara utuh dan terpadu. Lebih lanjut disebutkan bahwa bahan ajar berfungsi sebagai: (1) pedoman bagi guru yang akan mengarahkan semu aktivitasnya dalam proses pembelajaran, sekaligus merupkan substansi kompetensi yang seharusnya diajarkan kepada siswa. (2) pedoman bagi siswa yang akan mengarahkan semua aktivitasnya dala proses pembelajaran, sekaligus merupakan substansi kompetensi yang seharusnya dipelajari/dikuasainya. (3) alat evaluasi pencapaian/penguasaan hasil pembelajaran.

Bahan ajar adalah merupakan seperangkat materi yang disusun secara sistematis sehigga tercipta lingkungan/suasana yang memungkinkan siswa untuk belajar. Sebuah bahan ajar paling tidak mencakup antara lain: (1) Petunjuk belajar (petunjuk siswa/guru), (2) Kompetensi yang akan dicapai, (3) Content atau isi materi pelajaran, (4) Informasi pendukung, (5) Latihan-latihan, (6) Petunjuk kerja, dapat berupa Lembar Kerja (LK), (7) Evaluasi, dan (8) Respon atau balikkan terhadap hasil evaluasi.

Dalam PP Nomor 19 Tahun 2005 Pasal 20, diisyaratkan bahwa guru diharapkan mnegembangkan materi pembelajaran, yang kemudian dipertegas melalui Peraturan Menteri Pendidikan Nasional (Permendiknas) Nomor 41 Tahun 2007 tentang Standar Proses, yang antara lain mengatur tentang perencanaan proses pembelajaran yang mensyaratkan bagi pendidik pada satuan pendidikan untuk mengembangkan Rencana Pelaksanaan Pembelajaran (RPP). Salah satu elemen dalam RPP adalah sumber belajar. Dengan demikian, guru diharapkan untuk mengembangkan bahan ajar sebagai salah satu sumber belajar.

\section{SIMPULAN}

Berdasarkan hasil penelitian dan pembahasan dapat ditarik kesimpulan, yaitu: isi draft buku IPA SD berbasis inkuiri yang dikembangkan, mencakup:

1. Judul bab, gambar pembuka bab, dan teks pengantar disajikan dengan tujuan untuk menarik perhatian dan memancing keingintahuan siswa ( fase Engage).

2. Peta pikiran, untuk memudahkan siswa memahami alur dari materi yang akan dipelajari (fase Engage).

3. Materi pelajaran disajikan sebagai salah satu sumber informasi untuk pendorong agar siswa dapat membentuk konsep (fase Explain).

4. Gambar dan ilustrasi disajikan untuk menambah motivasi siswa dalam penemuan (fase Explain).

5. Tahukah kamu berisi informasi actual yang berkaitan dengan konsep yang dipelajari sehingga siswa mampu memecahkan kesulitan yang dihadapi baik secara individu maupun secara berkelompok (fase Elaborate).

6. Mari cari tahu dan mari kita selidiki berbentuk lembar kegiatan dan diskusi disajikan untuk memberi kesempatan kepada siswa agar bekerja sama dalam menjawab pertanyaan dan melakukan pengamatan (fase Explore).

7. Mari bertukar pikiran sebagai bagian untuk pendorong agar siswa dapat menjelaskan konsep dengan kata-kata sendir atau pembentukkan konsep (fase Explain.)

8. Mari mengingat kembali sebagai bagian untuk mengukur tingkat pemahaman siswa tentang konsep yang sduah ditemukan (fase Evaluate).

\section{SARAN}

Berdasarkan kesimpulan penelitian pengembangan buku IPA SD berbasis inkuiri untuk meningkatkan sikap ilmiah dan berpikir kritis bagi siswa SD, peneliti ingin menyampaikan saran-saran sebagai berikut ini: 
1. Penyusunan peta konsep akan lebih menantang siswa berpikir jika sebagian kotak konsep dikosongkan dan diminta siswa yang mengisinya.

2. Untuk kegiatan Mari cari tahu dan Mari kita selidiki berbentuk lembar kegiatan dan diskusi sebagai implementasi fase ekplorasi dapat ditambahkan kegiatan yang dilakukan di rumah sebagai pekerjaan rumah.

\section{DAFTAR PUSTAKA}

Hair, Joseph, F.Jr; Anderson, R,E; dan Black, William, C. 1995. Multivariate Data Analysis With Reading. Fourth Edition. Englewood Cliffs, New Jersey: PrenticeHall, Inc. A Simon and Schuster Company.

PP Nomor 19 Tahun 2005

Winarni, Endang, W. 2009e . Upaya Peningkatan Kompetensi Guru Dan Hasil Belajar Inkuiri Untuk Meningkatkan Pemahaman Konsep, Kemampuan Berpikir Kritis, dan Sikap Ilmiah Siswa kelas V SD pada konsep penyesuaian Makhluk Hidup.. Jurnal Pembelajaran Sains, FKIP UNIVERSITAS Mulawarman, Samarinda: Volume 1 No. 2, Agustus 2009. Hal:221222. ISSN 1978-2616.

Winarni, Endang, W. 2007c . Pengembangan Pembelajaran Sains Kontekstual melalui Strategi Inkuiri dan Masyarakat Belajar untuk Mengembangkan Kompetensi Guru dan Life-Skills Siswa SD.Lembaga Penelitian Unib: Laporan Hibah Bersaing DP2M Dikti, Tahun 2007.

Winarni, Endang, W. 2007b . Pengaruh Metode Kooperatif dan Kemampuan Akademik terhadap Pemahaman Konsep, kemampuan berpikir Kritis, dan Sikap Ilmiah Siswa Kelas 5 SD. Makalah disampaikan pada Forum Semirata Bidang MIPA BKS-PTN Wilayah Barat di UIN Jakarta, Juli 2007.

Winarni, Endang, W. 2006b . Pengaruh Startegi Pembelajaran terhadap Pemahaman Konsep IPA, Kemampuan Berpikir Kritis, dan Sikap Ilmiah Siswa kelas V SD dengan Tingkat Akademik Berbeda Di Kota Bengkulu. Disertasi. PPS Universitas Negeri Malang. Tidak Dipublikasikan

Winarni, Endang, W. 2006a .Pembelajaran Kontekstual dengan Metode Inkuiri Terbimbing pada Pelajaran IPA untuk Meningkatkan Penguasaan Konsep Siswa Kelas V SD 69 Bengkulu. Jurnal MIPA dan Pengajarannya. MIPA UM Tahun 35 No. 2, Juli 2006 (211-223). ISSN 08548269. Akreditasi DIKTI No. 39/DIKTI/Kep?2004 tgl 10 Nopember 2004. 